\title{
The portrait of the underground economy and tax evasion: Descriptive analysis from border region
}

\author{
Aloysius Hari Kristianto*, Pramatatya Resindra Widya, and Jones Parlindungan Nadapdap \\ Institut Shanti Bhuana, Bengkayang, Indonesia \\ *Correspondence email: harialoysius@gmail.com
}

\section{ARTICLE INFO}

- Research Article

Article History

Received 10 February 2021

Accepted 28 May 2021

Published 1 October 2021

\section{Keywords}

border area; corruption; tax evasion; underground economy

\section{JEL Classification D73; E26; O17}

\begin{abstract}
Underground economic activity is a phenomenon that requires special and continuous treatment. This phenomenon is counterproductive to local revenues and is related to corrupt practices and tax evasion. The research was conducted in Bengkayang Regency, West Kalimantan Province, Indonesia. The qualitative phenomenological method was carried out by interviewing underground economic actors such as liquor producers, "pangku" coffee shops, and street vendors. The findings indicate that corruption activities in the form of collecting bribes and offering bribes are carried out in cash without going through a legal transaction mechanism. The underground economy practices tax evasion, does business without a permit, pays substandard wages, and does not protect workers with insurance. The underground economic activity will contribute to an increase in the circulation of money in society, but do not take into account the regional economy. Such situations call for massive supervision of individuals and the introduction of pentahelix elements to form synergies between actors and to begin to integrate and develop digital structures in every financial activity using e-government systems.
\end{abstract}

To cite this article: Kristianto, A. H., Widya, P. R., \& Nadapdap, J. P. (2021). The portrait of the underground economy and tax evasion: Description analysis from border region. Journal of Socioeconomics and Development, 4(2), 156-165. https://doi.org/10.31328/jsed.v4i2.2211

\section{INTRODUCTION}

National income is one of the benchmarks for the country's economic indicator. It is hoped that the correct calculation of national income will be able to contribute to the national economy and identify which sectors contribute to the development and which ones need to be strengthened sectors in order to support the social development. Underground economic practices are an important part of numerous countries, both developed and emerging. Economic operations are carried out both lawfully and unlawfully, the latter of which are not detected in the calculation of national income/GDP (Schneider \& Hametner, 2014). During the 2001-2013 period, Indonesia's underground economic growth was $8.33 \%$ of GDP. As a result, there is a possible revenue deficit of $11,172.86$ billion rupiahs, or around $1 \%$ of GDP, which covers market output of legitimate and illicit products and services that are exported or purchased illegally (Samuda, 2016).

Based on the findings of Feige (1990), the underground economy is classified into four groups: (i) the illegal economy: commercial activity that breaks laws such as the selling of stolen goods, slavery, smuggling, bribery, trafficking and drugs, (ii) the unreported economy: failure to disclose income to the tax authority concerned, (iii) an unrecorded economy: lack of statistical evidence on income for the 
government and (iv) an informal economy: commercial actors that receive income without a business license, a job arrangement and a loan from an official financial institution (Azwar \& Mulyawan, 2017). Measuring the level of the underground economy is not an easy assignment with a challenging level of precision. Optimal fiscal policy related to tax collection and administration needs to be more positive and pro-economic actors so that they can become registered business actors for contributing to GDP and being the target be the subsidies policy of the SME (Small Medium Enterprises) industry (Asaminew, 2010). Underground economic activity is an enterprise that produces revenue beyond the knowledge of the tax authority with a view to tax evasion, and involves the informal sector and the black market, which is commonly referred to as the illegal market.

The sluggishness of Indonesian SMEs is exacerbated by a range of social cognition errors. This social cognition is derived from cultural understanding shared in newspapers by the Indonesian government and citizens. There are perception-related shortcomings among market players, such as systemic philosophy, structuralism, and social learning. Due to the shortcomings of Indonesian SMEs, there is a need for collaborative research based on a philosophical approach to science. The low growth of SMEs in Indonesia is due to a lack of understanding among business players about how to build a business while considering social aspects such as salaries in compliance with government policy, employee health assurance, acceptable business practices and sufficient rewards for employees (Panjaitan et al., 2020).

Black markets were created as a result of overly rigid government controls and prohibitions on products entering the market. The unregulated market is illegal even with the lawful allocation of sales and market share. Production and distribution of products on the black market is illegal and violates state law. Illegal market descriptions are highly associated with informal sector activity such as small business units, self-employed employees, unregistered enterprises, low access to credit facilities, and position in border and peripheral regions (Faal, 2003).

Tax management policies frequently fail to be implemented due to many factors such as the civil servants' poor expertise in taxation, the indiscipline of business players, and mistrust of state agencies
(Pravasanti, 2018). Fiscal policy commitment through moderate tax cuts and constant tight supervision will reduce the amount of underground economic activity and provide a boost for the regional economy, thus increasing regional government fiscal revenues (Orsi et al., 2014). The high level of tax pressures imposed on business players, the level of cash money supply, and unemployment add to increased tax evasion activity (Amoh \& Adafula, 2019).

The approach of raising tax rates is intended to raise the amount of government revenue. However, this action will lead to future tax deviations and disincentive to the population in carrying out economic activities, thus enabling people to enter the underground economy (Azwar \& Mulyawan, 2017). Increased underground economic growth will cause problems with poor fiscal decentralization policies and particularly growing regional economy in local level (Kanao et al., 2010). The general stereotype against performers in the underground economy is slum, filthy, disorderly, poor-ordered trade facility, unorganized business, unpleasant street vendors (Schneider, 2014). This characterizes the condition of the economy segment, namely the relatively limited size of operation, local resource reliance, time and location versatility and relatively simple accessibility (Tanzi \& Fund, 2014; Wa Ode, 2015). Unfortunately, this underground economy continues to grow and becomes the choice of underground economic actors to survive. Such constraints as low employment opportunities and low quality of human resources encourage many people to engage in informal work.

There is a positive correlation between the degree of corruption and the actions of underground economic players, as shown by a limited circulation of money in a monetary point of view and the transaction value is not calculated by GDP. This can reduce state and local revenue accounts and show pseudo national economic activity. High levels of corruption diminish public confidence in government authorities, which can influence tax evasion and increase underground economic activity (Marè et al., 2020). The increasing activity of the underground economy in the form of bribery and criminal acts of corruption has worsened the image of law enforcement and the rule of law (Marliza Mohamed, 2012).

The complex bureaucratic pressure makes underground economic players choose alternate routes in all areas and seek security to keep their business going normally (Ouédraogo, 2017). To 
foresee and control the issue of underground economic crime, the government must be prepared to take decisive action relating to underground economic operations by partnering with industrial organizations to engage in digital technology (An \& Kim, 2018). By enhancing the micro and small enterprises to access the global economy, the amount of underground

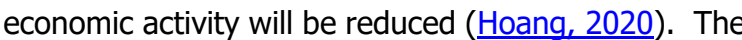
significance of an integrated framework between scientific disciplines, particularly law and crime, with an integrated approach to deal with the actions of underground economic actors and bribery behavior (Andreev et al., 2018).

To date, the activities of underground economic actors in Indonesia have not been clearly enforced and specified. It is important to address a continuous analysis in order to devise policies responding to the conditions of underground economic actors in each area of Indonesia. Some argue that the underground economy is a means of de-industrialization and socia isolation, as shown by a decrease in social and individual freedoms, which leads to social inequality and poverty (Chotim et al., 2019).

Many studies on underground economic estimation have been carried out. The underground economy estimates from the consumption side show an estimated yield equivalent to $40 \%$ of GDP. This amount indicates the existence of tax evasion business practices or hidden dishonest business practices that do not generate a contribution to GDP (Nizar \& Purnomo, 2011). Findings by Faal (2003) using a monetary approach clarified that the economy was underground in Guyana from 1964 to 2000, in which the tax burden could change the market for currency by introducing a major tax component. Measurement of the scale of the underground economy gives rise to demand for variable currency-M1 (monetary money) as a result of the implementation of Tanzi's standard model of demand for money (Samuda, 2016). Theoretically, the bank interest rate would have a negative effect on the demand for money, which means that if there is a decline in the amount of demand for money, the public chooses to save money in the form of a deposit (Kristianto, 2019). However, the condition is different if the society chooses to circulate money for commercial activities rather than save it in the form of investments with the bigger return of the benefits compared to that which are used for business, even though the interest rate of the deposit rises (Furuoka \& Munir, 2014).
The research is aimed to estimate the underground economy in the border region. The research location was in Bengkayang Regency, West Kalimantan Province, Indonesia. This region borders the country of Malaysia, in particular the state of Sarawak on the island of Borneo. The underground economic potential in this region has been in the spotlight for a long time, implying opportunities for abuse of authority and corruption which affect regional growth.

\section{RESEARCH METHOD}

This study uses a qualitative phenomenological method, which is a technique to explain descriptions interpreted by an individual from his life experience holistically. This study observes the behavior of the underground economy business, the events experienced, and the responses or business processes. A triangulation method approach was used to collect evidence and data, which included in-depth interviews, participatory observations, and recordings in natural settings that were responsive to the respondent and research site.

The research was conducted in Bengkayang Regency, West Kalimantan Province. It is the outer region of the province which is directly adjacent to the Sarawak state of Malaysia. The underground economy player was interviewed to elaborate on their characteristics related to the type of business, business experience, and the kind of illegal activities, such as the practice of paying retribution/taxes, bribery, illegal levies, and extortion.

Respondents selection in this study is done based on the John W. Creswell approach, where the researcher chose respondents intentionally, and actively and thoroughly arranged respondents and places (documentation or visual material) to find more understanding and analysis of the problem being reviewed. The number of respondents in a heterogeneous group ranges from 3 to 15 people (Creswell, 2014). This study collected data from an unpublished respondent source. The selection of key respondents was done deliberately, related to the identification of locations and individuals/groups, including street vendors (legal and illegal), coffee shops, and liquor producers in Bengkayang market traditional. The survey selected eight key respondents (Table 1), including two coffee shops, two street vendors, two beer producers, and two wholesalers. They have shown an understanding of taxes as a 
regional contribution. They generally pay illegal fees without valid evidence for the purpose of maintaining the cleanliness and security of the area.

Table 1. Respondents and Business Type

\begin{tabular}{cl}
\hline Name & Business Type \\
\hline A1 & Coffee Shop 1 \\
A2 & Coffee Shop 2 \\
A3 & Street Vendor 1 \\
A4 & Street Vendor 2 \\
A5 & Liquor producer 1 \\
A6 & Liquor producer 2 \\
A7 & Grocery Store 1 \\
A8 & Grocery Store 2 \\
\hline
\end{tabular}

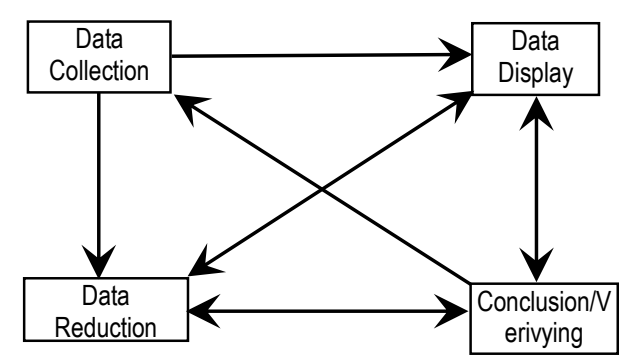

Figure 1. Analysis Method adapted from (Miles et al., 2014).

The data analysis method was carried out in a three-stage descriptive narrative, namely data reduction, data presentation and data verification to draw conclusions (Miles et al., 2014). The steps of the data processing can be seen in Figure 1.

\section{RESULT AND DISCUSSION}

\section{Respondent Characteristics}

The underground economy is an activity that is difficult to quantify. However, some knowledge that refers to the definition or characteristics of underground economic actors can be found in the Bengkayang area for the purpose of the study (Table 2).

Table 2 shows that business actors had an educational background profile of Junior High School (SMP) and Senior High School (SMA). Workers work more than eight hours per day. The wages received by workers were less than the regional minimum wage in the Bengkayang area. Economic actors did not include workers in welfare or social security programs. Indonesia's low ownership of work-accident insurance and social security is impacted by the informal workers' level of education or understanding. Overall, labor accident insurance ownership among unskilled workers underground economy sector is relatively low (Madya \& Nurwahyuni, 2019).

Long and cumbersome bureaucracy and procedures make business players unwilling to apply for and register for business licenses for taxpayer ID (NPWP). This inefficient service is supposed to foster high levels of corruption and corruption along with weak institutional frameworks to assist underground economy improvement (Ouédraogo, 2017). Corruption cases must be taken care of with strict regulation, and make it standard for clean government performance in winning community trust (Berqgren \& Bjørnskov, 2020). Massive elimination of corruption must be done with a trustworthy government system and the anti-corruption committee (KPK) as an independent institution in prosecuting corruption cases (Samimi \& Abedini, 2012).

\section{Underground Economy Activities}

The circumstances and practices of underground economic in relation to levies, unauthorized business licenses and taxes evasion are presented in Table 3.

Table 2. Respondent Characteristics of Underground Economy Activity

\begin{tabular}{|c|c|c|c|c|c|c|c|c|}
\hline Properties & A1 & $\mathrm{A} 2$ & A3 & A4 & A5 & A6 & A7 & A8 \\
\hline Education level & SMP & SMP & SMP & SMP & SMA & SMA & SMA & SMA \\
\hline Wage level & $<$ UMR & $<$ UMR & $<$ UMR & $<$ UMR & $<$ UMR & $<$ UMR & $<$ UMR & $<$ UMR \\
\hline Employee Social Security & No & No & No & No & No & No & No & No \\
\hline NPWP (taxpayer ID) & No & No & No & No & No & No & No & No \\
\hline Business license & No & No & No & No & No & No & No & No \\
\hline Total Manpower (person) & $<5$ & $<5$ & $<5$ & $<5$ & $<5$ & $<5$ & $<5$ & $<5$ \\
\hline Length of working (years) & $>5$ & $<5$ & $>5$ & $>5$ & $<5$ & $>5$ & $<5$ & $>5$ \\
\hline
\end{tabular}

SMP: Junior High School, SMA: Senior High School, UMR: minimum regional wage 
Table 3. Data on Information Relating to Taxes and Licenses

\begin{tabular}{|c|c|c|}
\hline & Retribution & Taxes/License \\
\hline $\mathrm{A} 1$ & $\begin{array}{l}\text { There is no change in the payment of the garbage/cleaning } \\
\text { services, the shop area is always filthy. Service is a } \\
\text { formality. }\end{array}$ & $\begin{array}{l}\text { There is no socialization on the issue of NPWP (taxpayer } \\
\text { ID) and government business licenses, as well as the } \\
\text { advantages of these taxes and the awareness of NPWP. }\end{array}$ \\
\hline$A 2$ & $\begin{array}{l}\text { Overlapping the payment of dues, certain economic actors } \\
\text { are exempt from paying payments relative to all economic } \\
\text { actors. }\end{array}$ & $\begin{array}{l}\text { NPWP is found no required, as there is little benefit. } \\
\text { However if the company is in violation of the legislation, } \\
\text { the business is likely moving instead }\end{array}$ \\
\hline A3 & Support payments from officers as security money & NPWP is not so necessary and useful \\
\hline A4 & $\begin{array}{l}\text { Food sector players are distinguished from coffee shops, } \\
\text { with a } 10 \% \text { contribution from turnover. }\end{array}$ & NPWP is not so essential and useful \\
\hline A5 & $\begin{array}{l}\text { The fees charged are voluntary donations, without } \\
\text { pressure from the group involved, and the fees paid are } \\
\text { meant for personal use, not for official purposes. Company } \\
\text { typically allocate security services of between } 200 \text { and } 300 \\
\text { thousand per person. The commitment is made every } \\
\text { month where the security forces coming in are between } \\
\text { two and three people. }\end{array}$ & $\begin{array}{l}\text { NPWP and business licenses are not necessary because } \\
\text { they believe that small companies are not taken into } \\
\text { account. Posibly, business are side enterprises of officials } \\
\text { and members of the board of directors. }\end{array}$ \\
\hline A6 & $\begin{array}{l}\text { The advantage of paying security service, in the case of a } \\
\text { raid is already given details from the unscrupulous. }\end{array}$ & $\begin{array}{l}\text { Company licenses do not exist because they sound } \\
\text { cumbersome and bureaucratic in the administration. }\end{array}$ \\
\hline A7 & Support payments from officers as security money & NPWP is not so essential and useful \\
\hline A8 & $\begin{array}{l}\text { When there is a raid there is a notice from the apparatus, } \\
\text { the payments will go to the Agency directly, not to the } \\
\text { Agency. }\end{array}$ & NPWP is not so essential and useful \\
\hline
\end{tabular}

The underground economic activity begins with bribes by perpetrators, which are carried out in cash without going through a legal banking system. The transaction process can be carried out by providing fake receipts or intentionally eliminating evidence of recording interbank transactions. The transaction process is carried out by the team in charge of managing the field, after which the agreed bribe quota is distributed. Cash transactions can increase the supply of cash (Uslaner \& Rothstein, 2016). Increased corruption will result in an increase in the circulation of money in society. Therefore, monitoring the circulation of individual money can be an option for extensive prevention of underground economic practices and tax evasion. The introduction of Penta helix elements is now possible to create synergies between stakeholders while starting to integrate and develop digitization structures in all financial activities using e-government payments and tax payment systems (Bhuiyan, 2011).

Commodities entering the border are carried out via alternate routes at many locations in the forest connecting Malaysia with Indonesia. These goods might be in the form of drugs, craft splits (typical Dayak mats), motor cars and alcoholic drinks. This is done to avoid border or customs control. Although not backed by a centralized organizational framework, smugglers continue to operate successfully with the aid of ubiquitous contemporary communication technology, allowing them to connect rapidly and globally to share relevant information, leaving no trace. They work through a variety of relationships with people who are able to provide different services such as providers of local lodging and transportation, document forgers, corrupt authorities, transportation firms, and more. Many of these networks are ethnic (Içduygu \& Toktas, 2002).

In order to ascertain the underground economy's contribution to the regional economy of the border area, this study conducted interviews with actors from the underground economy, including grocery stores, street sellers, coffee shops, and liquor producers, each of which was represented by two business actors. The interviews found that the majority of respondents said that the motive for beginning a business was to make money. As such, the community operated a grocery store, market stands, coffee shops, and liquor producers in order to make ends meet.

Research shows that the working hours imposed were not in accordance with applicable regulations. The underground economy business employed their workers more than eight hours a day. Respondents said that all grocery store owners, street vendors, coffee shops, and alcohol sellers did not have NPWP or social security for their employees. The respondents 
put forward several reasons for not having NPWP and social security for their company, as explained below.

"We receive very little information about NPWP and business licensing procedure. There is almost no correspondence between us as business communities and local government, and we don't understand the process [of acquiring NPWP]." (Grocery store 1).

The next statement showed business actors did not feel the need to get NPWP.

"If information dissemination and mentorship continue on an ongoing basis, we as entrepreneurs will obey the laws as long as our business can expand in the future. Don't hamper tiny enterprises like us. At least provide us appropriate infrastructure and facilities." (Grocery store 2)

"For me, you know, [for] little businesses [like what] we operate, NPWP and business licenses are not that necessary. I think it is more vital to take care of medium and large enterprises. " (Coffee shop 1).

Another explanation why business actors did not wish to have an NPWP was the complex and longstanding bureaucracy. This was mentioned by the following business actor.

"The lengthy procedure and poor service make us hesitant to take care [of it]." (Coffee shop 2)

For business actors, the use of NPWP is an indicator that the business being run is officially operational. However, dissemination about the importance of NPWP for business actors was not carried out. Business actors claimed that it was hard to obtain NPWP and considered it unnecessary, which became their justification to run an underground economy business.

This study also confirmed the findings of Rothenberg (2016) who researched the informal economy sector in Indonesia. The market actors in the informal sector or the underground economy will live in an illegal position because they do not experience any loss due to the illegal status of their business. Fundamentally, the underground economy carried out by these local entrepreneurs will become a drain on the regional economy as well as on the national economy (Montenegro, 2010).

As acknowledged by research respondents, these underground economic traders paid a retribution fee to run their business, including environmental cleaning fees and security charges. Several respondents asserted that these payments were indirect contributions intended for thugs rather than authorized officials (Williams, 2015). Rothenberg et al. (2016) stated that uncontrolled business involvement in the underground economy can have a negative impact on tax revenues, market dynamics, and productivity. In term of economic contribution, according to research respondents, these dark economy traders were likely to be able to run their businesses. The underground economy according to Williams \& Horodnic (2017) creates a situation that can harm regional growth, regional income, and the capacity for corruption within the apparatus. The more widespread the corruption in an area, the more underground economic actors appear there (Wiseman, 2015). The following findings confirmed this abuse of authority.

"We have an insider to aid the process. We are ready to pay for the inducement if there is an issue so we are not too worried. "(Coffee shop 2)

"We paid the levy to the officials. If an unannounced inspection takes place, they would notify us to get ready. "(Liquor producer 2).

"We don't dare to argue with them because they include the local security apparatus, so we just pay them so they don't take over. "(Liquor producer 1)

Qualitative research was performed to understand the role of the underground economy in the border area. The underground economy is all types of economic activity that are not registered and do not contribute to the account of a gross national/regional product or the regional economy, while their activities indicate that they are flowing and used for personal benefit (Strapuc \& Hlaciuc, 2019). If we pay attention to the market situations of underground economic amid economic hardships created by the COVID-19 pandemic, it was indicated that those business actors can still thrive, while in other circumstances many large-scale and legitimate business actors have suffered deficits. This is stated in the following statement.

"During the crisis, raw material costs go up while purchase price stays down." (Street vendor 1).

"I even sell, order and import alcohol from bordering areas, but no one has ever found out about it. " (Coffee shop 2).

"The wine production number varies according to the demand, with 2,000 to 3,000 kilos of wine sold at Rp25,000 a week. " (Liquor producer 1). 
This fact proves that underground business owners can run a company even during difficult times. Overall the study results show that underground economy actors have the potential to support the economy of the region. This confirms the findings of research conducted by Rasbin (2013) that during the period 2001 to 2013, the underground economy accounted for $8.33 \%$ of Indonesia's GDP. The scope for tax losses is also very high, exceeding $1 \%$ of Indonesia's average quarterly GDP.

\section{Research Implication}

The respondents in the underground economy revealed that the majority of them were hesitant to apply for a company license and to get a taxpayer identification number (NPWP) because it was difficult and they believed their operations were constantly watched. Workers were not included in welfare or social security programs since they were considered as economic players. It is believed that the low degree of ownership of work accident insurance and social security in Indonesia is affected by the education or conditions of the informal employees. In general, the number of participants in occupational accident insurance is low among unskilled employees in the underground economy, especially those who work in hazardous conditions (Madya \& Nurwahyuni, 2019).

Underground economic activity was carried out in cash transactions without going through the legal banking system. Hence, providing a payment and transaction processing digitization system is extremely helpful. This digitization system may connect various institutions such as tax agencies, commercial offices, community associations, police, and labor administration services. This integration may be in the form of creating big data with a robust server security system. Implementing big data processing may improve the life cycle of the collecting, processing and storing process. It can also provide links to support effective organization, improvement of data availability and processing speed, and reliable and secure data storage (Dobrolyubova et al., 2019).

It should be noted that the underground economy research encompasses the complexities of the relationships and the characteristics of the actors concerned, rules of engagement, values, and culture that govern an economy (Dermawan, 2010). Legitimation by politicians enables the underground economy to maintain tax evasion and unethical behavior. Political influence and corruption create a societal culture that renders repressive powers ineffective (Nurunnabi, 2019). The fields of public administration and sociology dominate the study of corruption. However, economists have conducted significant research on this topic. According to the Transparency International Agency, corruption is "the misuse of delegated authority for personal gain." While the damage caused by corruption has long been studied, there is no evidence of its effect on inflation. Between 1995 and 2015, the relationship between corruption and inflation was examined for twenty countries. The findings indicated that high levels of corruption raise inflation rates and that a unidirectional causal link exists between corruption and inflation in ten countries (Ozsahin \& Ucler, 2017).

Although corruption and an ineffective judiciary will breach ethical standards and result in other negative consequences, they should not have to intensify social injustice. Additionally, while the judiciary's quality has a good connotation, it may indicate the polar opposite. However, we must stress that corruption and judicial accountability also have an effect on long-term development, which is why engaging in accountability and combating corruption would result in true success for the entire society. In general, these two considerations will also influence the quality of national balance data whether the rich gets away with corruption by diverting consumption to other countries or by engaging in unethical practices to conceal income and consumption from conventional measures. Furthermore, distributional reforms have no means of determining whether corruption and systemic transparency have an impact on social mobility levels. When considering policy proposals aimed at combating graft and enhancing judicial transparency, it is critical to exercise caution of unintended consequences on high distribution margins (Berggren \& Bjørnskov, 2020).

The research findings show that underground economy business owners do not have permission from the tax authorities and reduce local government tax revenues. The reasons business actors do not register their businesses legally are because they do not have the expertise, do not trust, or do not want to deal with the complexity of legal arrangements by the tax authorities. Local governments should start collecting data and immediately implement programs to enable underground economic actors to run the economy legally and engage in official economic activities. This will have an impact on increasing local 
tax revenues which will encourage regional economic growth. There should be socialization, assistance, and ongoing community preparedness about important information needed for sustainable regional growth (Ozsahin \& Ucler, 2017). The enforced program needs to impose social sanctions in the form of annual reports on graft incidents and tax restitution. Enforcement of national policies is possible to build commitment and integrity of governance. There is a need for stricter regulations against perpetrators of corruption because corruption is contrary to human rights and contains a very significant political agenda.

\section{CONCLUSION AND SUGGESTION}

This study proves that business actors are reluctant to apply for and register business permits and taxpayer ID (NPWP) because of the complicated bureaucratic process. This is because they also lack knowledge and information about the needs and benefits of working legal businesses for the regional economy. The underground economy actors prefer to pay the penalty illegally because this situation for them is more adequately handled.

The performance of underground economic actors further shows violations of legal regulations, including tax evasion, providing wages below the regional minimum standards, not providing social assurance for workers, employing people beyond working hours, as well as paying illegal levies to certain people under the pretext of cleaning and security fees.

The underground economic situation must be addressed immediately by changing the perspective of economic actors so that their activities bring benefits to company growth and contribute to the regional economy. Quality government governance will provide feedback from tax payments, and assist the business world with facilities such as micro business loans, adequate infrastructure and facilities, and taxes based on the capacity of business actors.

This study suggests the implementation of an information technology-based financial system. A system that connects various institutions such as tax agencies, commercial offices, community associations, police and labor administration services. Implementing big data processing may improve the mechanism of the collecting, processing and storing process to prevent tax evasion and underground economic behavior.

\section{REFERENCES}

Amoh, J. K., \& Adafula, B. (2019). An estimation of the underground economy and tax evasion: Empirical analysis from an emerging economy. Journal of Money Laundering Control, 22(4), 626-645. https://doi.org/10.1108/JMLC-01-2019-0002

An, J., \& Kim, H. W. (2018). A data analytics approach to the cybercrime underground economy. IEEE Access, 6(c), 26636-26652. https://doi.org/10.1109/ACCESS.2018.2831667

Andreev, A. S., Andreeva, O. V., Bondareva, G. V., \& Osyak, V. V. (2018). Understanding the underground economy. European Research Studies Journal, 21(2), 814-822. Retrieved from https://www.ersj.eu/journal/1332/download

Asaminew, E. (2010). The Underground Economy and Tax Evasion in Ethiopia: Implications for Tax Policy. Macroeconomic Division Ethiopian Economic Policy Research Institute, 1-26. Retrieved http://www.csae.ox.ac.uk/conferences/2011edia/papers/130-asaminew.pdf

Azwar, \& Mulyawan, A. M. (2017). Analisis Underground Economy Indonesia dan Potensi Penerimaan Pajak. Jurnal Info Artha, 1(1), 60-78. Retrieved from https://doi.org/10.2139/ssrn.3004254

Badulescu, A. (2011). The underground economy: What is the influence of the discount factor? African Journal of Business Management, 5(16), 7050-7054. https://doi.org/10.5897/AJBM11.1192

Berggren, N., \& Bjørnskov, C. (2020). Corruption, judicial accountability and inequality: Unfair procedures may benefit the worst-off. Journal of Economic Behavior and Organization, 170, 341354. https://doi.org/10.1016/j.jebo.2019.12.010

Bhuiyan, S. H. (2011). Modernizing Bangladesh public administration through e-governance: Benefits and challenges. Government Information Quarterly, 28(1), 54-65. https://doi.org/10.1016/j.giq.2010.04.006

Chotim, E. E., Fawzia, D., Halim, P., \& Badruddin, S. (2019). The underground economy, deindustrialization, and poverty: A study on the trade network of textiles and product textiles in Indonesia. International Journal of Innovation, Creativity and Change, 9(1), 95-115. Retrieved from https://www.ijicc.net/images/vol9iss1/9106_Choti m_2019_E_R.pdf 
Creswell. (2014). Research Design: qualitative, quantitative and mixec methods approaches. SAGE Publications Inc.

Dermawan, M. K. (2010). Underground economy dan kejahatan birokrat. Jurnal Masyarakat Dan Budaya, 12(2), 277-306 https://doi.org/10.14203/jmb.v12i2.113

Dobrolyubova, E., Klochkova, E., \& Alexandrov, O. (2019). Digitalization and effective government: what is the cause and what is the effect? In Communications in Computer and Information Science. Springer. https://doi.org/10.1007/978-3030-37858-5_5

Faal, E. (2003). Currency demand, the underground economy, and tax evasion: The case of Guyana. IMF Working Papers, 03(7), 1. https://doi.org/10.5089/9781451842432.001

Feige, E. L. (1990). Defining and estimating underground and informal economies: The new institutional economics approach. World Development, 18(7), 989-1002. https://doi.org/10.1016/0305-750X(90)90081-8

Furuoka, F., \& Munir, Q. (2014). Unemployment and inflation in Malaysia: Evidence from Error Correction Model. Philippone Journal of Development, 1(1), 35-45. Retrieved from https://www.ums.edu.my/mjbe/images/mjbe/vol1 /article 3.pdf

Herlina Wa Ode, et. al. (2015). Strategi pengembangan usaha sektor informal dalam meningkatkan pendapatan pedagang kaki lima di Kecamatan Kambu Kota Kendari. Jurnal Administrasi Bisnis (JAB), 3(1), 125-134. https://doi.org/10.52423/bujab.v3i1.9611

Hoang, H. (2020). The underground economy in transition countries from the perspective of globalization: The case of Vietnam. Revista Amazonia Investiga, 9(29), 234-242. https://doi.org/10.34069/ai/2020.29.05.26

Içduygu, A., \& Toktas, S. (2002). How do smuggling and trafficking operate via irregular border crossings in the Middle East? Evidence from Fieldwork in Turkey. International Migration Journal, 40(6). https://doi.org/10.1111/14682435.00222

Kanao, Koji, H. dan, \& Shigeyuki. (2010). The size of the underground economy in Japan. Munich Personal RePec Archive, 24064. Retrieved from https://mpra.ub.uni-muenchen.de/21562/

Kristianto, A. H. (2019). Analyzing the influence of interest rates on money demand according to Keynesian Theory. Msdj Shanti Bhuana, 1(1), 38-
47.

Retrieved

from https://journal.shantibhuana.ac.id/index.php/msd /article/view/99

Marè, M., Motroni, A., \& Porcelli, F. (2020). How family ties affect trust, tax morale and underground economy. Journal of Economic Behavior and Organization, 174, 235-252. https://doi.org/10.1016/j.jebo.2020.02.010

Marliza Mohamed. (2012). Estimating the underground economy from the tax gap: The case of Malaysia. Malaysian Journal of Economic Studies, 49(2), 91-109. Retrieved from http://ijie.um.edu.my/index.php/MJES/article/dow nload/2859/1033

Miles, Huberman, \& Saldana. (2014). Qualitative Data Analysis (Third Edit). SAGE Publications Inc.

Montenegro, F. S. A. B. C. E. (2010). Shadow economies all over the world new estimates for 162 countries from 1999 to 2007. Policy Research Working Paper WPS5356 5356, 72(3), 779-786. https://doi.org/10.1007/s12665-013-3001-z

Nizar, M. A., \& Purnomo, K. (2011). Potensi penerimaan pajak dari underground economy di Indonesia. Kajian Ekonomi Dan Keuangan, 15, 1$38 . \quad$ Retrieved from https://fiskal.kemenkeu.go.id/ejournal/index.php/ kek/article/download/93/81

Nurunnabi, M. (2019). Political influence and tax evasion in Bangladesh: What went wrong? Emerald Publishing Limited, 26, 113-134. https://doi.org/10.1108/s1058749720190000026007

Madya, S. D., \& Nurwahyuni, A. (2019). Determinan sosial ekonomi kepemilikan jaminan kecelakaan kerja pada tenaga kerja informal di Indonesia: Analisis data Susenas 2017. Jurnal Ekonomi Kesehatan Indonesia, 3(2). https://doi.org/10.7454/eki.v3i2.2990

Orsi, R., Raggi, D., \& Turino, F. (2014). Size, trend, and policy implications of the underground economy. Review of Economic Dynamics, 17(3), 417-436. https://doi.org/10.1016/j.red.2013.11.001

Ouédraogo, I. M. (2017). Governance, corruption, and the informal economy. Modern Economy, 08(02), 256-271. https://doi.org/10.4236/me.2017.82018

Ozsahin, S., \& Ucler, G. (2017). The consequences of corruption on inflation in developing countries: Evidence from panel cointegration and causality tests. Economies, 5(49). https://doi.org/10.3390/economies5040049 
Panjaitan, J. M. P., Timur, R. P., \& Sumiyana, S (2020). How does the Government of Indonesia empower SMEs? An analysis of the social cognition found in newspapers. Journal of Entrepreneurship in Emerging Economies, 6(1), 1-11. https://doi.org/10.1108/JEEE-04-2020-0087

Pravasanti, Y. A. (2018). Dampak kebijakan dan keberhasilan tax amnesty bagi perekonomian Indonesia. Kompartemen: Jurnal Ilmiah Akuntansi, 16(1), 84-94. Retrieved from https://doi.org/ 10.30595/kompartemen.v16i1.2415

Rasbin. (2013). Ekspektasi Potensi underground economy di Indonesia. Kajian, 18(3), 229-239. https://doi.org/10.22212/kajian.v18i3.493

Rothenberg, A. D., Gaduh, A., Burger, N. E., Chazali, C., Tjandraningsih, I., Radikun, R., Sutera, C., \& Weilant, S. (2016). Rethinking Indonesia's informal sector. World Development, 80, 96-113. https://doi.org/10.1016/j.worlddev.2015.11.005

Samimi, A. J., \& Abedini, M. (2012). Control of corruption and inflation tax: New evidence from selected developing countries. Procedia - Social and Behavioral Sciences, 62, 441-445. https://doi.org/10.1016/j.sbspro.2012.09.072

Samuda, S. J. A. (2016). Underground economy in Indonesia. Buletin Ekonomi Moneter Dan Perbankan, 19(1), 39-56. https://doi.org/10.21098/bemp.v19i1.599

Schneider, F. (2014). In the shadow of the state - the informal economy and informal economy labor force. Danube, 5(4), 227-248. https://doi.org/10.2478/danb-2014-0013

Schneider, F., \& Hametner, B. (2014). The shadow economy in Colombia: Size and effects on economic growth. Peace Economics, Peace Science and Public Policy, 20(2), 293-325. https://doi.org/10.1515/peps-2013-0059

Strapuc, C., \& Hlaciuc, E. (2019). Public governance and the underground economy. The USV Annals of Economic and Public Administration, 19(1 (29)), 142-152. Retrieved from www.annals.seap.usv.ro

Tanzi, V., \& Fund, I. M. (2014). The shadow economy , its causes and its consequences. International Seminar on the Shadow Economy Index in Brazil," Brazilian Institute of Ethics in Competition, July. Retrieved from https://citeseerx.ist.psu.edu/viewdoc/download?d oi=10.1.1.581.4386\&rep=rep1\&type=pdf

Uslaner, E. M., \& Rothstein, B. (2016). The historical roots of corruption. Journal of Comparative Politics, 227-248. https://doi.org/10.1017/9781108241281

Williams, C. C. (2015). Cross-national variations in the scale of informal employment: An exploratory analysis of 41 less developed economies. International Journal of Manpower, 36(2), 118135. https://doi.org/10.1108/IJM-01-2014-0021

Williams, C. C., \& Horodnic, I. A. (2017). Evaluating the relationship between social exclusion and participation in the informal sector in the European Union. International Journal of Manpower, 38(3), 489-503. https://doi.org/10.1108/IJM-10-20150179

Wiseman, T. (2015). Entrepreneurship, corruption, and the size of US underground economies. Journal of Entrepreneurship and Public Policy, 4(3), 313-330. https://doi.org/10.1108/JEPP-042014-0018 